Gibson Ncube

Gibson Ncube is a Postdoctoral Fellow in the Department of Modern Foreign Languages at Stellenbosch University. His interests are in gender/queer studies, cultural studies in Africa. Email: ncubegibson@yahoo.fr
Of dirt, disinfection and purgation: Discursive construction of state violence in selected contemporary Zimbabwean literature

\title{
Of dirt, disinfection and purgation: Discursive construction of state violence in selected contemporary Zimbabwean literature
}

This paper examines post-independent Zimbabwean literary narratives which engage with how the ruling ZANU-PF government frames dissenting voices as constituting dirt, filth and undesirability. Making use of Achille Mbembe's postulations on the "vulgarity of power" and Kenneth W. Harrow's readings of the politics of dirt, the central thesis of this paper is that the troping of dirt and state sponsored violence are closely related to the themes of memory and belonging. Literary works by writers such as Chistopher Mlalazi, NoViolet Bulawayo and John Eppel become self-effacing speech acts that are involved in reimagining and revisioning our understanding of power dynamics and how this affects human and social experiences. Keywords: discursive construction, dissenting voices, filth and disease, Gukurahundi massacres, state violence, Operation Murambatsvina, politics of dirt, power, memory and belonging, nationalism, Zimbabwean literature.

Dirt, filth and disease are tropes that figure prominently in Zimbabwean politics and political discourses. These tropes have been used by the ruling party and government to frame dissenting voices and all other forms of being that are perceived as deviating from the normative codes of the so-called Zimbabwean national identity. The hyper ethnocentric nationalist constructions of cleanliness and dirtiness, of purity and impurity have certainly drawn on the callous colonial patterns of the Rhodesian regime which used segregation to separate the "clean" whiteness from the rogue and not so clean blackness.

I will argue in this paper that the moralisation and politicisation of dirt has in Zimbabwe been demonstrative of diverse and multi-layered governmental misgivings and anxieties that it considered a challenge to its rule, power and control. Ashleigh Harris (44) rightly explains that the moralising discourses of dirt should be "read as a palimpsest, superimposed onto colonial and Afrocentric discourses of cleanliness and dirt, and as such, neither unexpected nor new, but rather, eerily predictable in their entanglement with the violent and exclusionary discourses of nationalist politics in Zimbabwe." Harris implies in this instance that post-independent state violence is predicated upon the violence of colonial Rhodesian state perpetrated acts 
of violence. The post-independent government thus simply replicates, if not perfects, the "physics" and "anatomy" of violence that had been used by the colonial Rhodesian government. Such violence is thus not new in anyway. What is new or different is the perpetrator and, in some instances, the victim of acts of state sponsored violence.

There are numerous examples of the deployment of the trope of dirt in postindependent Zimbabwe. For instance, two years after the attainment of independence, the notion of filth was used to designate dissenting voices in the regions of Matabeleland and the Midlands in what has come to be known as the Gukurahundi massacres. In the early 2000s, the same trope was used to refer to white commercial farmers who according to government discourses had benefitted from a dirty history. In 2005, Didymus Mutasa, the then Minister for State Security and Land Reform, was blatant in his comparison of white farmers to filth:

Operation Murambatsvina should also be applied to farms that are still in the hands of the whites. White farmers are dirty and should be cleaned out. The government will not hesitate to take their farms to resettle the black people who failed to get land during the distribution exercise. They (whites) are similar to the filth that was in the streets before Operation Murambatsvina (Radio Africa).

In addition to the violent removal of white farmers from their farms at the beginning of the 2000s, Mutasa calls for a further "cleaning" by ensuring that all remaining whites are dispossessed of their farms. This narrative and "inflammatory anti-white racist rhetoric" (Coltart 269) in which white commercial farmers were framed as dirty and therefore undesirable is also aptly captured by the protagonist in Chenjerai Hove's novel Bones. The protagonist points out:

There is disease on the land. Disease spreads on the land like a mat, with everybody seeing it and not wanting to shout it to the whole village. Disease spreads with the coming of those who have walked the land without knees. The people without knees have knelt and broken their legs on our land, so they will not leave to go to the land of their fathers. (Hove 54)

The whites, "people without knees", are conceived as being diseased and carrying with them an infection that affects not just the moral and cultural fabric of the nation but more importantly the very land itself. Karin Alexander (194) explains that such a discourse "has subjected the white minority to a rhetoric that frames them as colonialist enemies not only of the state but also of the black majority". This same metaphor and trope of disease is used to refer to opposition parties. The opposition Movement for Democratic Change, for example, was said to be a "dirty condom-smelly, sticky, damp, diseased and distasteful" (Kubatana Blogs). The condom is used usually to prevent the transmission of sexually transmitted diseases. In this instance, the opposition party is said to be supposedly used by the 
West. The ensuing adjectives are all negative and designate the opposition party as diseased and unclean.

Even the lesbian, gay, bisexual and transgender (LGBT) community has not been spared from the inscription of dirt and filth on their bodies. Likened to dogs and pigs, LGBT individuals are considered "the festering finger, endangering the body of the nation" (Shoko 634) and therefore deserve to be cut off from the robust, healthy body of the nation. In August 2016, in the aftermath of citizen protests against the ZANU-PF government, the tropes of dirt and filth were evoked yet again. The Road Verges Maintenance, a statutory corporation which was promulgated as a means of ensuring that roads and verges, especially in the capital city of Harare, are kept in clean and tidy manner. Those found guilty of contravening this statutory instrument were liable to a fine or a prison sentence of three months or both fine and imprisonment. Although this is not bad in itself, the promulgation of this law seems to be in reaction to dissenting voices that have lamented the continued running down of the country. This is a similar reaction, as I have shown above, to all forms of other and dissenting voices that challenge the government.

Moreover, in the last five years, infighting within the ruling party has seen the same trope of dirt and disease constantly reiterated at public functions with the aim of inscribing dissidence of certain party functions. A faction led by then Vice-President Joyce Mujuru was called zvipfukuto which is the Shona word for weevils. A weevil is a small beetle whose larvae develop inside stems and seeds of different plants. Such a name implies that this faction of the ruling party is a destructive force which is attacking the party from within, the same way that weevils attack crops from within seeds and plants. The opposing faction, led by Emmerson Mnangagwa, was called "Gamatox" which is a pesticide. This faction thus proposes itself as a pesticide that attempts to rid the party of destructive pests. Oliver Nyambi in his analysis of naming of political factions explains that:

The nicknames are derived from a pest and pesticide metaphor used by Didymus Mutasa in one of his widely circulated verbal affront on the Mnangagwa faction when, disturbed by the relentless vilification of the Mujuru faction which often bordered on treason, Mutasa fought back by depicting the Mnangagwa faction as a group of infiltrators who wanted to destroy the party from within. He likened the Mnangagwa faction to weevils that deserved to be treated with Gamatox. (62)

Gibson Ncube and Bridget Chinouriri (9) also point out that "what is interesting with the two nicknames of the factions is the metaphor of pest and pesticide. The metaphor of the pesticide alludes to the state of decay that is found within that faction of the ruling party". They conclude in this line of thought that "nicknaming the other faction as a pesticide frames that faction as a salvatory force that sought to ensure that the party was not infiltrated by putrefying agents" (Ncube and Chinouriri 9). 
Such naming of political factions within ZANU-PF simply replicates the tropes of dirt and disease which this party has consistently deployed in its labelling of opposing voices and bodies.

In his seminal work On the Postcolony, Achille Mbembe analyses the manner in which power is deployed. He contends that there is imperative need "to go beyond the binary categories used in standard interpretations of domination, such as resistance vs. passivity, autonomy vs. subjection, state vs. civil society, hegemony vs. counter-hegemony, totalisation vs. detotalisation" (Mbembe 103). Through an analysis of Cameroon, he proposed that the exercise of power in the postcolony is often "grotesque and obscene" (Mbembe 103). He further asserts that in the postcolony, "the state considered itself simultaneously as indistinguishable from society and the upholder of the law and the keeper of the truth. The state was embodied in a single person, the president. He alone controlled the law, and he could, on his own, grant or abolish liberties-since these are, after all, malleable" (Mbembe 105). Mbembe's assertions are particularly relevant in the case of post-independent Zimbabwe where Robert Mugabe, through the ruling party and government, has had the prerogative of deciding what forms of being are deemed correct and therefore lawful.

As I have previously discussed, the government of Zimbabwe has since the attainment of independence made use of the tropes of dirt, filth and disease to refer to dissenting and other/othered voices. Such troping of dirt and disease in national discourse is intimately related to the exercise of state power and domination. Mbembe (110) explains on the exercise of power that: "To exercise authority is, above all, to tire out the bodies of those under it, to disempower them not so much to increase their productivity as to ensure their maximum docility." By labelling dissenting voices and bodies as unclean and diseased, the post-independent Zimbabwean government has sought at once to keep under strict surveillance the nation whilst entrenching its own matrices of power and domination. The logic of dirt, as argued by Alicia Decker (491) in her analysis of Uganda, "provided the state with a more 'legitimate' means of eliminating political dissent". In the case of Zimbabwe, the use of the trope of dirt has been perpetually redeployed to deal with and squash diverse forms of dissidence.

In her conceptualisation of dirt and purity, Mary Douglas (5) explains that in cultures and societies which are "richly organised by ideas of contagion and purification, the individual is in the grip of iron-hard categories of thought which are heavily safeguarded by rules of avoidance and punishments". Douglas (4) earlier points out that "ideas about separating, purifying, demarcating and punishing transgressions have as their main function to impose system on an inherently untidy experience". In my analysis of the Zimbabwean situation after independence, I contend that "cleaning", "cleansing" and "sanitising" proposed by the government did not necessarily bring order, but rather imposed a certain form 
of order and logic that it views as appropriate. These "cleaning" exercises, often violent and fatal, evidently attempt to punish those considered dirty and unclean or responsible for causing dirt.

Such a state of affairs needs to be understood within the wider context of Zimbabwean nationalism. In his reading of modern nations and nationalism, Homi Bhabha (212) posits that there is need to "begin by questioning that progressive metaphor of modern social cohesion - the many as one" which reduces differences into "unitary collective experiences". Citizens of a nation, regardless of race, gender, class or ethnicity, are merged through the homogenising discourse that creates a unitary "patriotic body politic" (Bhabha 212). Such a totalising and homogenising discourse inevitably downplays minority or dissenting discourses, leading to what Julia Kristeva (34) terms the "demassification of the problematic of difference". Applying such reading of the concept of nation to Zimbabwe, Ngwabi Bhebe and Terence Ranger contend that the ruling ZANU-PF government since independence sought to create a unitary nation whose roots where grounded on Shona historicity and culture. They cite Robert Mugabe who states that Zimbabwe is a "natural Shona nation" given that:

The distinguishing features of our nation, cultural homogeneity, our biological and genetic identity, our social system, our geography, our history which together characterise our national identity, also combined in producing out of our people a national, vigorous and positive spirit which manifests itself in the consistently singular direction of its own preservation. (Mugabe cited in Bhebe and Ranger xxvi)

Such thinking of a singular homogenous nation, as accentuated above by the repeated use of the possessive adjective "our", frames any form of straying from the collective as an attack on the stability, coherence and cohesion of the nation. It thus become imperative to clean out or punish destabilising elements or individuals.

The question of punishment fits neatly into Michel Foucault's postulations in his pioneering text Punish and Discipline in which he discusses "ways of organising the power to punish" (130). Through processes he refers to as "panopticism", Foucault (197) problematizes that human societies have sought to observe everyday actions of inhabitants. He describes such societies as being: "[E]nclosed, segmented space, observed at every point, in which the individuals are inserted in a fixed place, in which the slightest movements are supervised, in which all events are recorded, in which an uninterrupted work of writing links the centre and periphery, in which power is exorcised without division". This is relevant in considering how so-called dirty or diseased bodies are put under surveillance by the government of Zimbabwe. When dissenting voices and dirty/diseased bodies are identified, discipline and "methods of control" (Foucault 211) become necessary. Foucault (215) further maintains in this regard that: "'Discipline' may be identified neither with an institution nor with an apparatus; it is a type of power, a modality for its exercise, comprising a whole set 
of instruments, techniques, procedures, levels of application, targets; it is a 'physics' or an 'anatomy' of power, a technology."

Through such a "physics" and "anatomy" of power, the ruling ZANU-PF has in Zimbabwe managed to constantly and effectively curtailed dissenting voices and this has operated in tandem with a "systematic silencing of alternative views" (Siziba and Ncube 518).

Instead of offering an exhaustive analysis of the deployment of the trope of dirt in state sponsored violence, I propose in this paper to examine two historical moments in which this trope has been used. I will analyse in the first instance the Gukurahundi massacres that took place in the Matabeleland and Midlands of Zimbabwe between 1982 and 1987. Secondly, I will look at "Operation Murambatsvina" which was an urban cleansing exercise which took place in the year 2005. The naming, grammar and vocabulary used in reference to these two historical moments is itself fascinating. Gukurahundi is the Shona term for the early summer rains that remove chuff and dirt from the fields whilst Murambatsvina can be loosely translated as "say no to filth/remove filth".

Through an exploration of literary narratives that capture various facets of the violently implemented Gukurahundi and Murambatsvina, I contend that literary works articulate the trope of dirt in an attempt to make sense, unpack and think through what it means to be Zimbabwean in the post-independent aftermath. As proposed by Michael Holquist (68), "literary texts, like other kinds of utterances depend not only on the activity of the author, but also on the place they hold in the social and historical forces at work when the text is produced and consumed". Lara (7-8) also concurs that literary narratives have the potential "to disclose previously unseen marginalisation, exclusion and prejudice [...] and that they are society's ways of coping with the past, the present, and a possible, utopian future". In this line of reasoning, literary narratives cannot be separated from the socio-historical context in which they are produced and ultimately received and "consumed". As argued by Ncube (477), literary narratives "offer a privileged space that is more than just a metalinguistic and autonomous edifice-more importantly, these texts offer a means through which individual, societal and cultural self-assessment and comprehension can be affected in the domain of quotidian life". What this means is that literary works play a pivotal role in constructing mediating spaces through which marginalised voices, discourses and histories are not only made visible but also rethought, revisioned and renegotiated.

I will begin by analysing the trope of dirt and the inherent state violence vis à vis the literary representation of Gukurahundi. Gukurahundi was initially used to refer to the protean armed force that was unleashed in areas of Matabeleland and Midlands provinces to quell dissent and unrest. The term is however now used to 
refer to the period between 1982 and 1987. An estimated 20000 civilians lost their lives during this period. David Coltart explains in The Struggle Continues: 50 Years of Tyranny in Zimbabwe, the callous brutality of state violence against those who were considered dissidents:

From late January to mid-March 1983, the Fifth Brigade murdered and tortured thousands of civilians, burnt hundreds of villages, and raped and pillaged entire communities. There were horrific public executions, people were lined up and shot in cold blood; on many occasions soldiers would arrive at villages with lists of people affiliated to ZAPU and those found would be assassinated in front of their families. On other occasions, entire families were herded into grass-roofed huts, which were then set alight. Pregnant women were bayonetted, killing the babies in their wombs. Young Ndebele men between the ages of 16 and 40 were particularly vulnerable and were frequently targeted and shot in cold blood. (139)

Not only does Coltart highlight above the gruesome and ruthless of the violence of the government backed army but more importantly the tribal and ethnic basis upon which the massacres were established and grounded.

Yvonne Vera's The Stone Virgins (2002), Christopher Mlalazi's Running with Mother (2012), Crispen Ndlovu's Guveya (2013), James Kilgore's We are all Zimbabwean Now (2011) and the poetry of John Eppel in the anthology Together: Stories and Poems (2011) are some literary works that offer graphic representations of this period which $\mathrm{Mu}-$ gabe defines as "a moment of madness" (Ellis 40). However, for the purpose of this paper, I will concentrate on the literary works by Mlalazi and Eppel. Coltart (143) goes on to highlight in this regard that: "Mugabe was cunning enough to deny that atrocities had taken place or to couch his language sufficiently ambiguously to avoid a nexus being made between his statements and the actions that followed." Wilfred Mhanda (181) also highlights in his autobiography Dzino: Memories of a Freedom Fighter, that Mugabe, a leader of government since independence, has through his discourses and actions, "been intolerant of divergent views and will brook no opposition. He has always been single-minded in his pursuit of power and will, in that regard, deal decisively with any obstacle, real or perceived". The above-mentioned novels offer a ghastly representation of how dissenting voices in the predominantly Ndebele provinces of Matabeleland and Midlands were dealt with during the Gukurahundi massacres.

In the novel Running with Mother by Christopher Mlalazi, a girl called Rudo witnesses her family, home and village being destroyed. Rudo's father is Ndebele and her mother is Shona. When the soldiers arrive at Rudo's village, they capture and kill all Ndebeles. Rudo's mother explains to her what she witnesses when the soldiers arrive at their family homestead: "The soldier locked both your two uncles and their families in their homes and then burned down all the huts before the bus came. [...] 
And they came to our house but when they heard me speak in Shona they told me to run away" (Mlalazi 17). Rudo and her mother survive because they speak Shona and because they have Shona names. As an allegory, Rudo's family represents the post-independent state. The father represents the Ndebele who are deemed dissident, thus dirty and needed to be eliminated through Gukurahundi, the rains that cleanse the fields of the chuff that prevents proper growth. The concept of rain certainly fits into ZANU-PF nationalism which in its functioning sought, and continues to seek, to cleanse and remove dirt from the metaphoric body of the nation. Gibson Ncube and Gugulethu Siziba offer an apt reading of this allegory of the family:

The absence and demise of the Ndebele father is particularly telling of the manner in which Gukurahundi sought to remove Ndebeles from authority. The role of the father figure in Running with Mother is taken over by the Shona mother who has to fend for and protect Rudo. The exclusion and demise of the father parallels the exclusion and demise of the Ndebeles in general in post-independent Zimbabwe (Ncube and Siziba 7).

The violent exclusion and elimination of the Ndebele father becomes an extended metaphor of how state violence sought to ensure that one ethnic grouping was viewed as dissident and thus undesirable. Rudo's village is ironically named Saphela. This name can be loosely translated from Ndebele as "we are annihilated". The soldiers seem to be out to completely annihilate all Ndebeles from this village. Such annihilation certainly fits in with the need to rid the post-independent state of all dirty and undesirable elements. Rudo, in her infantile reasoning believes that the massacring of the Ndebeles in her village was an attempt to enslave them: "Were those soldiers doing all those horrifying things - cutting of people's hands, burning them in their homes, stripping adults naked, beating them and herding them like cattle into a pen were they trying to turn the Ndebele people into slaves of the Shona?" (Mlalazi 117).

Rudo is unable to see that what was happening as more than just an attempt to enslave the Ndebele. In essence, Gukurahundi was a form of ethnic cleansing whose aim was to subdue any form of dissidence emanating from the Matabeleland and Midlands regions. It is worth pointing out that an exercise that sought to crush dissenting voices, through the cleansing of the Matabeleland and Midlands landscape, ended up being an ethnic cleansing in which Ndebeles were either tortured, maimed or killed.

John Eppel's poetry equally depicts the trauma and the complexities of state violence that plays out during Gukurahundi. In the collection of poems and short-stories published together with the late Julius Chingono, Eppel portrays the violence of Gukurahundi through the presentation of vivid fragments in which the soldiers are perpetrating untold acts of sadistic brutality. In the poem "Songbird" the persona states:

She was harbouring a dissident in her womb;

they unseamed her with a bayonet; 
it dangled from her umbilicus

like a jolly-jumper.

And the doves sang:

gukura

hundi,

gukura

hundi.

Little children of "traitors",

transformed by heavy blows-

they use branches, batons, iron bars-

to pumpkins about to spill their seeds.

And the hornbills cry:

vana

we nyoka

inyoka

wo futi (118)

In the first stanza of the poem, Eppel captures the manner in which a pregnant woman has her womb ripped open as it was claimed she was carrying a traitor. The choice of the verb "unseam" is telling at once of the callousness of the act as well as the degree of brutality considering that this unseaming was being done by way of a bayonet. What is interesting in here is the manner in which the trope of dirt is amplified by the introduction of the metaphor of the nyoka or snake. This metaphor undoubtedly serves to vilify the dissenting voices and thus justify state violence. This allusion to the snake evokes Mugabe's words at the onset of the massacres: "The only way to deal effectively with a snake, is to strike and destroy its head" (Chikhuwa 137). The snake usually symbolises betrayal. This biblical allusion casts the snake as cause of destruction and discord. By framing dissenting voices as snakes, this government discourse bestows upon itself a redemptive mission of ridding the nation of undesirable elements. Moreover, the crushing of the head of the snake justifies the state violence as pivotal to ridding the nation of treacherous and harmful and untoward elements. What is further remarkable about this poem is how Eppel ends each stanza with words in Shona. The use of the language of the perpetrator of violence serves to accentuate brutal acts being described in the poem. The poem however attributes the words in Shona to birds, doves and a hornbill. The dove often symbolises peace and love whilst the hornbill itself a bird on the brink of extinction. Attributing violent words to a bird associated with peace and love and another almost extinct bird serves to amplify the brutality that is expressed in the preceding lines. 
This same unassuming and shocking candidness is evident in the depiction of Operation Murambatsvina. In elections held in 2000 and 2002, Mugabe and his party experienced the first formidable attack to his rule since Zimbabwe attained independence. Almost all urban centres voted for the opposition MDC party. As the ruling government had hitherto reacted to dissenting voices, the urban populace needed to be symbolically and literally cleansed for having erred in voting for the opposition party. Describing how Operation Murambatsvina began in Bulawayo with the attack of city vendors, Coltart (423) explains that: "armed police had arrived without warning, systematically 'cleansing' the area, expelling all the vendors and, at the same time, confiscating their wares". Valerie Tagwira's The Uncertainty of Hope (2006) offers a fascinating depiction of the tumultuous events surrounding Operation Maurambatsvina. However, for the purpose of this paper, I focus on the depiction of this cleansing of urban centres in NoViolet Bulawayo's novel We Need New Names (2013). This is because of the considerable scholarship that already exists on Tagwira and her representation of Operation Murambatsvina.

Although she does not explicitly state in the novel that she is describing Operation Murambatsvina, NoViolet Bulawayo's We Need New Names aptly captures the tumultuous period when the government razed to the ground buildings and structures that were deemed too dirty to be part of the urban panorama. In the first part of the novel, Bulawayo describes the life of Darling, who grows up in a shanty town amidst a general environment of economic and social difficulties. Bulawayo ironically calls the shanty town Paradise and such naming beckons the reader to perceive of this space as a utopic home in spite of all the horrors and sadness that abound there. Darling describes the shanty town that she calls home in this way: "Paradise is all tin and stretches out in the sun like a wet sheepskin nailed on the ground to dry [...] The shacks themselves are terrible but from up here, they seem much better, almost beautiful even, it's like I'm looking at a painting." (Bulawayo 36)

Darling sees beyond the tin and the sheepskin that makes up the shanty town of Paradise. In fact, her description gives Paradise an idyllic sense of home in spite of the harshness and crudeness of quotidian life there. By comparing Paradise to a painting, Darling shows her attachment to her home and how it is not only dear to her but also how she finds it beautiful in spite of its apparent imperfections. However, the government views this place that Darling considers home as an eyesore that needed sanitising. Darling recounts the trauma associated with the destruction of their homes: "Then the lorries come carrying the police... and we run and hide inside the houses, but it's no use hiding because the bulldozers start bulldozing and bulldozing and we are screaming and screaming" (Bulawayo 67).

When all the demolition and clearing of what is deemed dirty, it is not a clean and sanitised space that remains. In fact, the ruthless operation leaves more trauma and suffering than had been the case before. Darling explains in this respect: "When 
the bulldozers finally leave, everything is broken, everything is smashed, everything is wrecked. It is sad faces everywhere, choking dust everywhere, broken walls and bricks everywhere, tears on people's faces everywhere" (Bulawayo 66). The repetition of the words "everything" and "everywhere" attests to how misery and brokenness abound in the aftermath of the operation. In his analysis of this operation and its effects, Harris (40) explains that "reasons for naming the operation "clean up filth" shows "how 'dirt' became moralised in the discourse surrounding Murambatsvina, and how this moralisation came to justify the operation in ZANU-PF view".

I further point out that the naming of this exercise in which people's homes and places of business were destroyed as an "operation" evokes the trope of disease. The medicalisation and pathologising of dirt and filth thus frames state violence against underprivileged bodies as necessary in order to remove the vile, foul and revolting constituent. Like a surgical operation, the clean-up intervention set out to bring about order and cleanliness. The exercise, however, caused more harm than good. As Coltart explains, "the long term consequences could not be fully spelt out then, but it is not unreasonable to speculate that Murambatsvina probably killed more people than the Gukurahundi because of the fatal combination of displacement, HIV/AIDS and poverty" (426). In spite of these abundant effects of the operation, state violence had achieved its objective of quelling dissenting voices that had burst forth in the urban areas after the March 2012 presidential elections which had seen the urban populations voting en masse for the opposition party.

The description of dissenting voices as dirt fits into the exclusionary practices of the Zimbabwean government which has sought to divide and rule. Susan Sontag (180) explains in this regard that the "militarising of language of dirt and disease" "not only provides a persuasive justification for authoritarian rule but implicitly suggests the necessity of state sponsored repression and violence (the equivalent of surgical removal or chemical control of the offending or 'unhealthy' parts of the body politic)" (180).

Douglas (2) expounds that "dirt offends against order. Eliminating it is not a negative movement, but a positive effort to organise the environment". She goes on to develop that "ideas about separating, purifying, demarcating and punishing transgressions have as their main function to impose system on an inherently untidy experience" (4). In as much Douglas' assertions are relevant in understanding how the poetics of dirt functions, I find that her claims can certainly not be applied when the offending dirt is a human being or group of human beings. Such a way of reasoning would indeed justify and vindicate cleansing exercises such as Gukurahundi and Operation Murambatsvina.

Literary narratives that broach the troping of dirt and dirtiness are in themselves important counter-hegemonic discourses. As rightly postulated by Pauline Dodgson- 
Katiyo, such works "create a space for [...] the otherwise forgotten or absent to be commemorated, documented, narrated and even felt" (17). Literary and artistic works do not only have the potential to disclose state violence but also play an important role in reclaiming censored narratives and histories. Yvonne Vera expounds in this light that, "as a writer, you don't want to suppress history, you want to be one of the people liberating stories" (cited in Bryce 226). Elsewhere, she points out that "to write is to engage possibilities for triumphant and repeated exits, inversion and recuperations of identity [...] Writing is resistance [...] to write is to banish silence" (Vera 93). As such, writing about the manner in which dissenting voices are framed as dirt becomes itself an act of defiance. This is achieved through giving voice to those voices that deemed deviant and dissenting and are thus muffled by dominant government discourses. Such voicing of muffled voices becomes a counter-discursive and counter-hegemonic process in which state violence is portrayed in its harsh brutality. The literary narratives that I have made reference to in this paper achieve more than just critiquing government sponsored violence and exclusionary practices. The narratives are involved more importantly in being edifices and processes of remembering the past. In this case I use the term remember in the sense of coalescing or bringing together dismembered histories, memories and indeed lives of those the government viewed as dirty and hence requiring silencing and cleansing.

I conclude that literary narratives are important in capturing diverse state violences in post-independent Zimbabwe and I quote Wade Adebanwi, who clarifies why works of art remain vital in the societies in which we live:

In observing the social process, both past and present, they reflect, and reflect on, extant perspectives in understanding reality by creating new maps of existence through ideas that not only generate, but also transcend existing possibilities and ways of apprehending those possibilities. In contributing to the common store of social, political and moral ideas in society, they also become wellsprings of new ideas and new ways of thinking (407).

For as long as human societies continue to exist, literature will continue to capture its complex and diverse functioning. Violently marginalised, side-lined and muffled histories and discourses are afforded a space in which they cannot only be revisited but can be rethought in a bid to better understand them and to accord them the rightful recognition they deserve.

\section{Works Cited}

Adebanwi Wade. "The Writer as Social Thinker." Journal of Contemporary African Studies, vol 32 no 4, 2014, pp. 405-20.

Alexander, Karin. "Orphans of the Empire: An Analysis of Elements of White Identity and Ideology Construction in Zimbabwe," Zimbabwe: Justice and Political Reconciliation, edited by Brian Raftopoulous and Tyrone Savage, Institute for Justice and Reconciliation, 2004, pp.193-212. 
Bhabha, Homi. "DissemiNation: Time, Narrative and the Margins of the Modern Nation." The Blackwell Reader in Contemporary Social Theory, edited by Anthony Elliot, Blackwell, 1999, pp. 211-19.

Bhebe, Ngwabi and Terence Ranger. The Historical Dimensions and Human Rights in Zimbabwe. U of Zimbabwe Publications, 2001.

Bryce, Jane. "Survival is in the mouth: Interview with Yvonne Vera." Sign and Taboo: Perspectives on the Poetic Fiction of Yvonne Vera, edited by Robert Muponde and Mandivavaira Maodzwa-Taruvinga, Weaver Press, 2002, pp. 217-26.

Bulawayo, NoViolet. We Need New Names. Chatto \& Windus, 2013.

Chikhuwa, Jacob Wilson. A Crisis of Governance: Zimbabwe. Algora Publishing, 2004.

Coltart, David. The Struggle Continues: 50 Years of Tyranny in Zimbabwe. Jacana Media, 2016.

Decker, Alicia. "Idi Amin's Dirty War: Subversion, Sabotage, and the Battle to Keep Uganda Clean. 1971-1979." The International Journal of African Historical Studies, vol 43 no 3, 2010, pp. 489-513.

Dodgson-Katiyo, Pauline. "Telling Versions of the War: Vera and the War's Legacy." Emerging Perspectives on Yvonne Vera, edited by Helen Cousins and Pauline Dodgson-Katiyo, Africa World Press, 2012, pp. $101-20$.

Douglas, Mary. Purity and Danger. An Analysis of Concept of Pollution and Taboo. Routledge, 1966.

Ellis, Robb W.J. Without Honour. CreateSpace, 2006.

Foucault, Michel. Discipline and Punish: The Birth of the Prison. Translated by Alan Sheridan. Vintage Books, 1995.

Harris, Ashleigh. "Discourses of Dirt and Diseases in Operation Murambatsvina." The Hidden Dimensions of Operation Murambatsvina, edited by Maurice Vambe, Weaver Press, 2008, pp. 40-52.

Harrow, Kenneth W. Trash: African Cinema from Below. Indiana U P, 2013.

Holquist, Michael. Dialogism: Bakhtin and His World. Routledge, 2002.

Hove, Chenjerai. Bones. Baobab Books, 1988.

Kristeva, Julia. “Women's Time." Signs, vol 7 no 1, 1981, pp. 13-35.

Kubatana Blogs. "It's Official: The MDC Has Sold Out." 2009. www.kubatanablogs.net/kubatana/itsofficial-the-mdc-has-sold-out/.

Lara, M. P. Moral Textures. Feminist Narratives in Public Sphere. Polity Press, 1998.

Mhanda, Wilfred. Dzino: Memories of a Freedom Fighter. Weaver Press, 2011.

Mlalazi, Christopher. Running with Mother. Weaver Press, 2012.

Ncube, Gibson. "Sexual/textual Politics: Rethinking Gender and Sexuality in Gay Moroccan Literature." Journal of Contemporary African Studies, vol 32 no 4, 2014, pp. 476-90.

Ncube, Gibson, and Gugulethu Siziba. "(Re)membering the Nation's 'Forgotten' Past: Portrayals of Gukurahundi in Zimbabwean Literature." Journal of Commonwealth Literature, vol 52 no 2, 2015, pp. 1-17, https://doi.org/10.1177/0021989415615646.

Ncube, Gibson, and Bridget Chinouriri. "Humour as Support and/or Opposition: Nicknaming Political Personalities and Movements in Post-independent Zimbabwe." IGAMA: African Journal of Onomastics, vol 1 no 1, 2016, pp. 1-12.

Nyambi, Oliver. "Of Weevils and Gamatox: Titles, Names and Nicknames in ZANU PF Succession Politics." African Identities, vol 14, no 1, 2016, pp. 59-73.

Phillips, Oliver. "'Venus Monstrosa' and 'Unnatural Offences.'" Sociolegal Control of Homosexuality: A Multination Comparison, edited by James West Donald and Richard Green, Plenum Press, 1997, pp. 43-60.

Radio Africa. "Racial Discrimination in Zimbabwe: A Systematic Programme of Abuse." 2012. http://nehandaradio.com/2012/11/30/racial-discrimination-in-zimbabwe-a-systematic-program-of-abuse-part-1/

Shoko, Tabona. "Worse Than Dogs and Pigs? Attitudes Toward Homosexual Practice in Zimbabwe." Journal of Homosexuality, vol 57 no 5, 2010, pp. 634-49.

Siziba, Gugulethu and Gibson Ncube. "Mugabe's Fall from Grace: Satire and Fictional Narratives as Silent Forms of Resistance in/on Zimbabwe." Social Dynamics, vol 41, no 3, 2015, pp. 516-39.

Sontag, Susan. Illness as Metaphor and AIDS and its Metaphor. Penguin Books, 1991.

Tagwira, Valerie. The Uncertainty of Hope. Weaver Press, 2006.

Vera, Yvonne. The Prison of the Colonial Space: Narratives of Resistance. 1995. York University, Toronto, PhD thesis. 